\title{
Coping with Firewood Scarcity in Soroti District of Eastern Uganda
}

\author{
Anthony Egeru $^{1^{*}}$, Eseza Kateregga ${ }^{2}$, Gilber Jackson Mwanjalolo Majaliwa ${ }^{1}$ \\ ${ }^{1}$ Department of Environmental Management, Makerere University, Kampala, Uganda \\ ${ }^{2}$ School of Economics and Management, Makerere University, Kampala, Uganda \\ Email: ${ }^{*}$ geru81@educ.mak.ac.ug
}

Received September $5^{\text {th }}$, 2013; revised October $26^{\text {th }}$, 2013; accepted November $18^{\text {th }}, 2013$

\begin{abstract}
Copyright (c) 2014 Anthony Egeru et al. This is an open access article distributed under the Creative Commons Attribution License, which permits unrestricted use, distribution, and reproduction in any medium, provided the original work is properly cited. In accordance of the Creative Commons Attribution License all Copyrights $₫$ 2014 are reserved for SCIRP and the owner of the intellectual property Anthony Egeru et al. All Copyright (C) 2014 are guarded by law and by SCIRP as a guardian.
\end{abstract}

\begin{abstract}
This study investigated how rural households cope with firewood scarcity in dryland areas of Eastern Uganda. A household survey was conducted in December 2008 to January 2009, where 490 respondents were randomly interviewed. Focus Group Discussions (FGDs) were also held with community elders and women. Responses were analyzed both descriptively and qualitatively. Findings indicated that $99 \%$ of the households used firewood for cooking with a per capita consumption of 542.32 Kilograms. Commonly used tree species included Combretnum molle (42.7\%) and Acacia polyacantha willd (18.2\%). Over 78\% of the households have a preference for acacia tree species for firewood. In particular, Acacia polyacantha willd (60.3\%), Acacia hockii (16.9\%) and Combretum collinum (9.6\%) were the most preferred tree species. The scarcity of firewood supply was eminent from the average distance $(2 \pm 7 \mathrm{Km})$ traveled by collectors in search of them. Firewood collectors spent 1 to 10 hours with an average of 3 hours weekly in firewood collection activities. This resulted in per annum estimated opportunity cost of Shillings 432,000 (US 232 dollars) for those who collected on weekly basis and Shillings 1,080,000 shillings (US 580 dollars) for those who collected on daily basis. The frequency of collection decreased as distance increased among $89 \%$ of the households. Minority of households (1\%) have resorted to deliberately planting trees on their own farms to ease problems of firewood shortage, and to modification of biomass stove so as to use less firewood. Households in their endeavour to circumvent the problem of continued scarcity have resorted to poorer quality tree/bushes for firewood (71.2\%), alongside other coping strategies such as cooking meals once a day, avoidance of cooking some food types (70\%), and using crop residues as fuel source (60\%). There is a need for scaling-up on-farm tree planting as well as the use of improved biomass cook stoves in the region.
\end{abstract}

Keywords: Adaptations; Household Energy; Firewood Scarcity; Soroti Uganda

\section{Introduction}

Firewood is the most significant source of energy in Uganda, and the majority of the people employ it for domestic use and small-scale industries such as brick and tile making, agroprocessing (sugar, tea, tobacco), jaggeries, bakery and fish processing (Population and Housing Census, 2002; Tabuti et al., 2003; Yikii et al., 2006). In urban areas, people use charcoal more than firewood. The 2005 Energy ministry annual report noted that for one kilogram of processed tea, one kilogram of wood is required (MEMD, 2005). This means that the tea processing alone consumes an equivalent of about 20 million metric tones of wood annually. At present, demand/consumption for firewood in Uganda is estimated to be growing at a rate of $2.5 \%$ per annum. According to the Food and Agriculture Organization estimates for Uganda, firewood consumption grew by more than 2 billion tons between the years 1993 and

\footnotetext{
*Corresponding author.
}

1997 (FAO, 1999; Tabuti et al., 2003). This growing demand is attributed to an increasing population, a growing industrial sector, as well as the increased rate of urbanisation and high household incomes (NEMA, 1988; Tabuti et al., 2003).

It is further projected that firewood will still supply more than $75 \%$ of the total energy consumption in the year 2015 (MFEP, 2000; UBOS, 2006). However, the firewood is already being felt in most part of the country. In Wakiso district of central Uganda for instance, firewood and charcoal, both by-products of wood, are scarce and the little that is available is sold at a high price, which can hardly be afforded by the poor urban and rural households (Nafula, 2008). A small piece of firewood costs between Uganda Shs 300 compared to Uganda Shs 50 a couple of years ago (Nafula, 2008). Some families now spend Uganda Shs 1000 on firewood everyday, but the majority live on less than a dollar a day (Nafula, 2008). According to the UN Population Fund, Uganda's population is predicted to be 130 million by 2025, almost five times the current number, and available wood will reduce by a third per person. The UN 
agency cited statistics that firewood collectors, mainly women and children, must travel increasingly long distances to collect an increasingly diminished resource. These longer journeys can be unsafe. And according to the country's National Environment Management Authority (NEMA, 1988), firewood scarcity means that some households are using foods that are easier to cook but potentially less nutritious. In Teso sub-region of eastern Uganda, there is a dearth of information on how the poor households cope with such impacts of dwindling firewood availability (DSOER, 1997, 2004). It is upon this background that study sought to the local adaptation strategies employed by these rural households to cope with the fuelwood problems in the region.

\section{Methodology}

Soroti District is located in Eastern Uganda, it lies approximately on latitudes $1^{\circ} 33^{\prime}$ and $2^{\circ} 23^{\prime}$ North off the equator, $30^{\circ} 01^{\prime}$ and $34^{\circ} 18^{\prime}$ degrees East of Prime Meridian and is over 2,500 feet above sea level with isolated rock outcrops. The district covers approximately $2662.5 \mathrm{~km}^{2}$ of which $2256.5 \mathrm{~km}^{2}$ is land and $406 \mathrm{~km}^{2}$ is water (Okori et al., 2002). The area is largely underlain by rocks of the basement complex pre-cambrian age which include; granites, mignalites, gneiss, schists, and quartzites with four major soil units; Serere and Amuria catena; Metu complex and Usuk series (DSER, 1997).

The vegetation of area is a mixture of woodlands, a wooded savanna, grass savannah, forests and riparian vegetation (DSER, 1997). Wooded savannah consists of moist Acacia savanna associated with Hyparrhenia spp and Combretum associated with Hyparrhenia ssp while Hyparrhenia spp, Themeda and Imperata cylindricum are the dominant grass savannah (DSER, 2004). Expanses of riparian vegetation (Wetland vegetation) with scattered tree grasslands associated with Setaria incrassate Hyparrheria rufa, Accacia sayel Acaccia fistula, Balanities aegyptica and Terminalia spp, Cyperus papyrus, Aeschynomen, Cyperus articulatus, Ulylectrum digitatum, Suddia sagitifolia (DSER, 1997; Byaruhanga \& Kigoolo, 2005) dominate. These wetlands are used as feeding areas by wading birds including the globally vulnerable species such as the shoebill (Balaeniceps rex), Fox Weaver (Ploceus spekeoides), Blue Quail (Coturnix adansonii), and Yellow-billed Ox-pecker (Buphagus africanus) and also do provide firewood (Byaruhanga \& Kigoolo 2005; NEMA 2006).

A stratified random sampling approach was then used; each parish was considered as an echelon that constituted an enumeration area (EA) consequently, Akoboi, Oburin, Okulonyo and Osuguro were echelons. At a 95\% confidence level, a 10\% household sample was withdrawn randomly from 4683 households in Olio for interview basing on Bryan (1992) selection procedure. This gave a sample size of 468 households with Akoboi (67), Oburin (135), Okulonyo (136), and Osuguro (131). However data was obtained from 490 households and four (4) focus group discussions (FDGs), one in each parish was conducted with an average attendance of 12 members. The responses obtained were tabulated, others coded, analyzed and descriptive statistics generated.

\section{Results}

\section{Per capita Firewood Consumption}

Findings indicate that $99 \%$ of the households used firewood for cooking and preserving food. Firewood used included twigs, freshly cut trees, dry logs, and crop residue inform of straws and stalks. The mean annual consumption of fuelwood was estimated at 3687.84 kilograms, giving a per capita consumption of 542.32 kilograms per user household. Therefore on average, weekly per capita consumption stood at 10.43 kilograms while daily per capita consumption translates to 1.49 kilograms. However, $25.9 \%$ and $22.4 \%$ of the households on average had a weekly consumption of 53.19 kilograms and 35.46 kilograms respectively.

\section{Commonly Used Firewood Tree Species}

Households commonly used combretnum molle (enyama) tree species for fuelwood (42.7\%); this was followed by Acacia polyacantha willd (egirigiroi) species at $18.2 \%$ (Figure 1). The argument for high reliance on combretnum molle was its easiness to split, availability and ability to rapidly regenerate. While those who relied on Acacia polyacantha willd argued that it had good burning qualities such as producing less smoke, ability to dry fast when spilt wet and its wood can retain fire for a long time (Table 1). There is however indiscriminate use of tree species for fuelwood among $71.2 \%$ of the households. Some of these tree species such as sarcocephalus latifolius (eutukidole), Vitex doniana (ewelo), Butyrospermum paradoxum (ekunguru), Prosopis africana (ekiki), and Erythrina abyssinica (engosorot), Vitex madienis (ekarukei), Piliostigma thonningi (epapai), Tamarindus indica (epeduru), Euphorbia candelabrum (epopong), Grewia mollis (eparis) and Milicia excelsa (elua) were traditionally forbidden for cooking. This is indicative of a decline in tree stock and depicts physical fuelwood scarcity in the area.

\section{Preferred Species, Their Perceived Availability and Desirable Qualities for Firewood}

Over $78 \%$ of the households have a preference for Acacia tree species for firewood. Overall, there is varying preference in particular tree species, for example acacia polyacantha willd (60.3\%), Acacia hockii (16.9\%), Combretum collinum (9.6\%), Combretum molle (3.3\%), Akero ${ }^{* *}(4.7 \%)$, Mangifera indica (2.6\%), Tamarindus indica (1.2\%) and acacia sieberiana (1.2\%) Figure 2. Of the preferred tree species, $52 \%$ of the households believed that they are not readily available, $27.9 \%$ as quite available and only $20.4 \%$ accepted that the tree species were available. The preference for these tree species was attributed to their good burning qualities including; long time fire retention and cultural acceptability in which no visitor can apprehend a

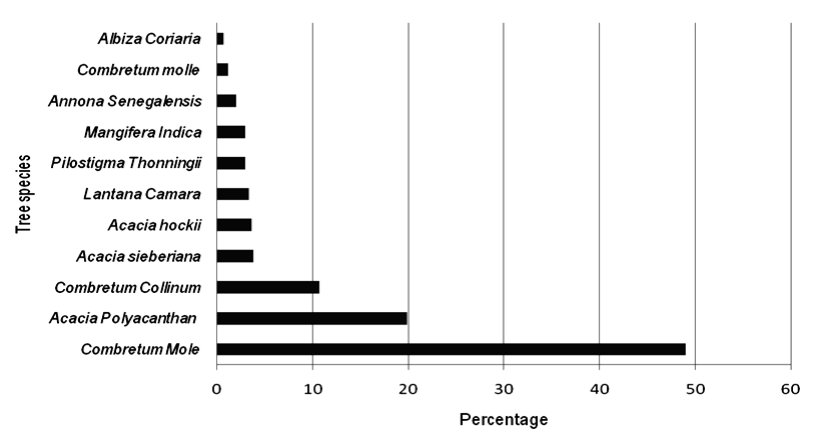

Figure 1.

Common tree species used for cooking $(\mathrm{N}=490)$. 


\section{A. EGERU ET AL}

Table 1.

Preferred species, their perceived availability and desirable qualities for firewood.

\begin{tabular}{|c|c|c|c|c|}
\hline Tree species & Local name & $\%$ response & Perceived availability & Desirable qualities of firewood \\
\hline Acacia polyacantha willd & Egirigiroi & $60.3 \%$ & Quite available & $\begin{array}{l}\text { Long time fire retention, less smoke, easy to spilt, } \\
\text { dries faster when spilt live and culturally acceptable }\end{array}$ \\
\hline Acacia hockii & Ekisim & $16.9 \%$ & Not readily available & Retains fire for a long time, culturally accepted. \\
\hline **** & Akero & $4.7 \%$ & Not readily available & Burns faster and easy to light \\
\hline Combretum collinum & Ekulony $^{* *}$ & $9.6 \%$ & Not readily available & Long hours of fire retention and produces less smoke \\
\hline Combretum molle & Enyama & $3.3 \%$ & Available & Re-grows rapidly when cut, cheaper than the rest when purchased \\
\hline Mangifera indica & Emyebe $^{* *}$ & $2.6 \%$ & Quite available & $\begin{array}{l}\text { Burns well even when not properly dry, available } \\
\text { within compounds and own land }\end{array}$ \\
\hline Tamarindus indica & Epeduru $^{* *}$ & $1.2 \%$ & Not readily available & Quite heavy and good for carbonization into charcoal \\
\hline Acacia sieberiana & Etirir & $1.2 \%$ & Not readily available & Good flame when properly dry and culturally acceptable \\
\hline Prosopis africana $^{*}$ & Eikik & ** & Not readily available & Hardwood good for building poles and oxen yokes \\
\hline Butyrospermum paradoxum ${ }^{*}$ & Ekunguru & ** & Not readily available & Hard and good for carbonization to charcoal \\
\hline
\end{tabular}

Note: $\mathrm{N}=490 ;{ }^{*}$ Sparse presence in the area; ${ }^{* *}$ Established during FGDs that these tree species are highly endangered because they are preferred by charcoal burners; ${ }^{* * *}$ Tree species name not yet identified.

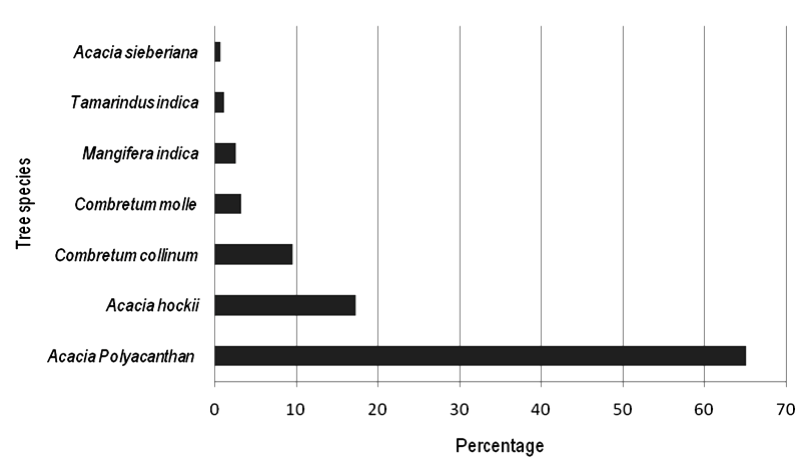

Figure 2.

Preferred Tree Species for Cooking $(\mathrm{N}=490)$.

woman for using tabooed trees for cooking (Table 1). However, Tamarindus indica, Combretnum molli, Prosopis africana, and Butyrospermum paradoxum are the most endangered tree species due to their multi-purpose use. The preference for specific tree species is tagged to perceived availability and specific desirable firewood qualities, a number of responses were obtained during the focus group discussions (Table 1).

\section{Household Responses to Firewood Scarcity}

The adaptive responses that have evolved are two way; the short term and long term coping mechanisms (Table 2). In the short term and immediate adaptation, $27.8 \%$ of the households extinguished fire after cooking. Further, modification of traditional cook stoves into a Lorena stove version was found among only $14.1 \%$ of the households. The stove is constructed out of local clay, bricks and a bicycle chainring (ananga) and to those who use, it was praised for saving firewood, keeping the fire for longer time, retaining heat for longer hours, providing a prolonged life span to cooking utensils and it allowed one to tend to other chores however, husbands complained that the food takes a longer time to get ready unlike when their wives use the three cooking stones.
Table 2.

Household adaptation strategies to firewood scarcity.

\begin{tabular}{cc}
\hline Strategies & \% response \\
\hline Modified firewood stove & 14.1 \\
Extinguishing fire after cooking & 27.8 \\
Planted any trees in 2008 & 24.7 \\
Planted trees specifically for firewood & 3.9 \\
Cutting of live trees for firewood & 34.8 \\
Use of crop residues for firewood & 60 \\
Indiscriminate use of tree species including \\
traditionally non-accepted species
\end{tabular}

Note: $\mathrm{N}=490 ;$; Issues a rose from the FGDs; ${ }^{* *}$ A common practice.

There is complimentary use of low quality burning species such as Ficus platyphylla, Ficus sycomorus, and Piliostigma thonningi with good quality burning species such as Markhamia lutea, Tamarindus indica, Acacia sieberiana, Combretum collinum, and acacia hockii. In addition, $71.2 \%$ of the households were involved in indiscriminate use of tree species, including traditionally non accepted species such as Sarcocephalus latifolius, Vitex doniana, Butyrospermum paradoxum, Prosopis africana, Erythrina abyssinica, Vitex madienis, Pilios- 
tigma thonningi, Tamaindus indica, Euphorbia candelabrum, Grewia mollis, Kigelia africana and Milicia excelsa.

About $60 \%$ of the households complimented firewood with crop residues of cassava stems, maize stalks and cobs and sorghum stalks. In addition, deliberate pruning/cutting of bush/ live trees as well as fruit trees constituted another response to firewood scarcity. There were no specific bush trees targeted for deliberate pruning however, pruning is done as long as they can burn and those closer to the homestead, fruit trees grown and pruned included Mangifera indica (emyebe) and citrus (emucunga) trees.

A commendable proportion of the households (39.4\%) purchased firewood in times of need as an adjustment to scarcity while housewives also resorted to sometimes cook once in a day and the food simply warmed for dinner. A strategy they argued saved time and energy, ensured that their children ate early before going to bed, saved them from conflicts with their husbands arising from the delayed dinner meals. Further, women avoided cooking certain types of grains especially beans which they complained required more firewood for a proper meal to come out. To eat these grains, their preparation was been modified, for example removing bean coatings using ash, and then cook it smashed. Housewives argued that they are at times found between a hard place and a rock when trying to have food at the table in time thus they resort to anything that can provide meaningful heat for cooking.

Agro-forestry has been adopted as a long term coping strategy; this constitutes the 'island' of success. The farmers plant a number of tree types including; high yielding and fast growing mangoes (Kent, Tommy, Apple and Boribo varieties), Citrus (Egyptian tang, sweet med, Washington, American tangerine and hamlin varieties), trees such as, pines, cashew nuts, jatropha (Ejumula), Eucalyptus and Grevillea robusta, and Markhamia lutea (emiti). The participants in agro-forestry are mainly retired civil servants who have devoted their time to agroforestry as a retirement package, as a pass time at old age and due to its profitability. They are though being challenged by climate variability given that the area lies within drylands' region, costs of inputs such as seeds and seedlings, availability and accessibility of inputs, pests and diseases, costs of labour, termites and some negative comments from some community members. In one of the FGDs a member remarked: "Trees have always been there, we found them here and they will be there, we did not plant and we do not need to plant, they grow alone", this is a clear sign of apathy towards agro-forestry that exists within the community.

\section{Discussion}

Soroti' average household size of 6.8 persons is above the national average of 5.6 persons (UBOS, 2007). Given the high growth rate at $5.1 \%$, it is a challenge to natural resource availability and management. According to Tenywa (2010) Uganda's population growth is third highest in the world, after Niger and Yemen. This population is heavily resilient on subsistence farming for both food security and income generation. This has led to a decline in woodland cover from $16.5 \%$ in 1990 , to $11.5 \%$ in 2005 (Tenywa, 2010). Further, Giannecchini (2007) observed that dependence on subsistence farming is an indication of land based activities being fundamental to household livelihoods. According Grunzweig et al. (2003), over reliance on crop cultivation leads to more tracks of land to be cleared caus- ing landcover changes. These changes escalate conflicts in the provision food, fuel and roughage on which the livelihoods of poor people critically depends (Bolwing \& Odeke, 2007). With continuous conversion, vegetation stock declines consequently resulting into increasing deforestation and increased distance traveled to collect firewood (Buyinza et al., 2008).

The over dependence of the households on firewood, first portrays the importance of traditional biomass energy in the households (ProudLock, 2007; Ahmet et al., 2008) and second, declares energy poverty in the area. According to MFPED, (2006) energy poverty is the absence of sufficient choice in accessing adequate, affordable, reliable, quality, safe, and environmentally benign energy services to support economic and human development. The other indicators of energy poverty in the area are low electricity and Photovoltaic energy (solar) services $4.7 \%$ and $0.4 \%$ respectively. This low consumption of modern fuels makes much envisioned industrialization difficult to attain. According to Hasen (1998), heavy dependence of rural households on firewood makes the anticipated depletion of stocks a real threat to economic welfare and growth. While the reliance on crop residues reinforces Cooke et al. (2008) argument that; the use of low quality fuel such as twigs, crop residues and dung is indicative of responses to higher fuelwood scarcity.

The per capita firewood consumption of 542.32 kilograms is slightly below the 629 kilograms per capita of wood Buyinza and Teera (2008) in Hoima (Uganda) and the 687 kilograms observed by Shackleton (1993) across twelve studies in South Africa. On the other hand Kalumian and Kisakye (2001) reported a lower consumption figure of 485 kilograms per capita in Nakasongola and Masindi districts (Uganda). We believe that these variations could be due to variations in cooking habits eminent in these regions of Uganda for example, Hoima lies in the Bantu and Luo dominated region where a variety of foods with various cooking habits prevail. For example, cooked plantain (matoke) requires longer hours of preparation compared to the millet bread (Atap/Kalo) prepared among the NiloHamites of Soroti. It could also be attributed to generally high reliance on the three cooking stones open fire place which according to Wiskerke, (2008) experiences very low thermal efficiencies. However, the use of open fires and poorly ventilated cooking shelters exposes women and girls who mainly perform the cooking roles to indoor air pollution which has effects such as Acute respiratory infections (ARI) and chronic asthma, eye sight and problems of chronic Pulmonary disease (Kubasu, 2007).

The indiscriminate use of tree species for firewood by $71.2 \%$ of the households in this study is similar to the findings of Sikei et al. (2009) in Kakamega Kenya where households out of disparateness switch to poorer wood with no specific preference for particular wood species. This equally portrays a breakdown in traditional customs regarding conservation owing to the dynamic use of species including the traditionally banned ones.

\section{Conclusion and Recommendations}

With the huge number of households still dependent on subsistence cultivation for survival, the area is in a spiral of problems including among others: rapid land conversion into crop land, vegetation stock depletion, continued increase in distance traveled to collect firewood, negligible savings and high risks of food insecurity due to crop failures and a likelihood of wor- 
sened climate change effects including intense floods, droughts and dust storms. This may further worsen the disequilibrium suffered by drylands given that they are one of the fragile ecosystems in the country. There is a clear breakdown in traditional customs regarding conservation. On the other hand, the low consumption of modern fuels makes much envisioned industrialization in the country difficult to attain. Though energy is not directly mentioned as one of the MDGs, it ought to be considered as a niche in the attainment of sustainable human development that will enhance the attainment of environmental sustainability (MDG7) with interlink effect to the attainment of MDG3 (promotion of equality and empowering women) and MDG1 (eradication of extreme hunger and poverty). The adaptations under use by the households need to be scaled up especially in agro-forestry which has shown both economic viability and social acceptability. Improved biomass energy stoves ought to be encouraged among the households and to reduce the cost burden, and household heads but more specifically, women, and local artisans ought to be trained on how to construct these stoves using locally available materials. However, some of the adaptations such as cutting of live trees need to be discouraged.

\section{Acknowledgements}

Agricultural innovations in Dryland Africa (AIDA) and Regional University's Forum for Capacity Building in Agriculture (RUFORUM) for funding.

\section{REFERENCES}

Ahmet, T., Ayahan, A., \& Mediha, O. (2008). Usage of trees and forest resources at household level: A case study of Asagi Yumrutas Village from the West Mediterranean Region of Turkey. Research Journal of Forestry, 2, 1-14.

http://dx.doi.org/10.3923/rjf.2008.1.14

Birikadde, G. K., Mating, M., \& Clancy, J. (2009). Fuel security and supply dynamics in internally displaced persons' camps of Northern Uganda. Journal of Humanitarian Assistance, April 29.

Buyinza, M., \& Teera, J. (2008). A system approach to fuelwood status in Uganda: A demand-supply nexus. Research Journal of Applied Sciences, 3, 264-275.

Bowlig, S., \& Odeke, M. (2007). Household food security effects of certified organics export production in tropical Africa: A gendered Analysis. Sida: EPOPA.

Byarunhanga, A., \& Kigoolo, S. (2005). Lake Bisina wetland system Ramsar information sheet (RIS). Kampala: Nature Uganda.

Cooke. P., Hyde, F., \& Kohlin, G. (2008). A wood fuel crisis: Where and for whom? (pp. 10-13). Tacoma, WA: Pacific Lutheran University.

Food and Agriculture Organization (FAO) (1999). FAO yearbook 1997: Forest products, 1993-1997. FAO Forestry Series, Vol. 32, Rome: Food and Agriculture Organization of the United Nations.

Grunzweig, J.M., Lin, T., Rotenberg, E., Schwartz, A., \& Yakir, D. (2003). Carbon sequestration in arid-land forest. Global Change Biology, 9, 791-799. http://dx.doi.org/10.1046/j.1365-2486.2003.00612.x

Gbetnkom, D. (2007). Forest management, gender and food security of the rural poor in Africa (7p). Helsinki: United Nations UniversityWIDER.

Hasen, B. (1998). Changing patterns of natural wood and resource dependency and use: Inter-generational perceptions, traditions and customs. A case study of Bushbuckridge District, Mpumalanga Province South Africa. Unpublished MA Thesis, Copenhagen: University of Copenhagen.

Kalumian, O. S., \& Kisakye, R. (2001). Study on the establishment of a sustainable charcoal production and licensing system in Masindi and Nakosongola District. EPED Project, Kampala: Ministry of Water, Lands and Environment, 17, 78p.

Kubasu, L. N. (2007). Improved biomass stoves improving livelihoods among displaced cattle rustling population in North Rift Kenya. Presentation-Beyond Fuel Conference, India, North Rift Kenya: Mwafrika Institute of Development (MID).

Li, A., Guangming, H., Zai, L., \& Jianguo, L. (2006). Impacts of demographic and socio-economic factors on spatio-temporal dynamics of panda habitat. Biodivserity and Conservation, 15, 2343-2363.

Ministry of Finance Planning and Economic Development (MFPED) (2000). Background to the budget 2000-2001 (10p). Kampala: Ministry of Finance Planning and Economic Development.

Ministry of Energy and Mineral Development (MEMD) (2005). Anual report. Kampala: Ministry of Energy and Mineral Development.

Nabinta, R. T., Yahaya, M. K., \& Olajide, B. R. (2007). Rural energy exploitation and utilization on sustainable development in Gomber State, Nigeria. Journal of Social Sciences, 15, 205-211.

Nafula, J. (2008). Saving money and the environment with efficient stoves. Daily Monitor (M2: Features), November 26, Kampala Uganda.

National Environment Management Authority (NEMA) (2007). State of the environment report for Uganda (78p). National Environment Management Authority.

National Environment Management Authority (NEMA) (1998). State of the environment report for Uganda. Kampala: NEMA.

Okori, A., Emuria, M., \& Ojuman, P. (2002). Uganda participatory poverty assessment process. Soroti District Report, Kampala: CDRN, MFPED.

Soroti District Environment Report (DSER) (1997). District state of the environment report for Soroti. Soroti: Soroti District Local Government.

Soroti District Environment Report (DSER) (2004). District state of the environment report for Soroti. Soroti: Soroti District Local Government.

Sikei, G., Mburu, J., \& Lagat, J. (2009). Rural households' response to fuelwood scarcity around Kakamega Forest, Western Kenya (pp. 7-8). Nairobi: African Research Consortium.

Tabuti, J. R. S., Dhillion, S. S., \& Lye, K. A. (2003). Fuelwood use in Bulamogi County in Uganda: Species selection, harvesting and consumption patterns. Biomass and Bioenergy, 25, 581-596.

Tenywa, G. (2010). Uganda: Water scarcity to hit country by 2035. The New Vision, March 16, Kampala: The New Vision Printing and Publishing Co. Ltd.

Uganda Bureau of Statistics (UBOS) (2006). Uganda National Household Survey (UNHS) 2005/2006 (40p). Kampala: Uganda Bureau of Statistics.

Uganda Bureau of Statistics (UBOS) (2007). Uganda National Household Survey (UNHS) 2005/2006: Report on the agricultural module (35p). Kampala: Uganda Bureau of Statistics.

Wiskerke, W. T. (2008). Towards a sustainable biomass energy supply for rural households in semi-arid Shinyanga, Tanzania: A cost/benefit analysis. Group Science, Technology and Society, Utrecht: Utrecht University.

Woomer, P., Musa, N. O., \& Savala, C. N. (2007). Greenhouse gas emissions by the United Nations Office of conference services and opportunities for carbon neutral operations (30p). Nairobi: Organic Resource Management and Agricultural Technologies.

Yikii, F., Agea, J. G., \& Kaboggoza, J. R. S. (2006). Eucalyptus versus indigenous trees: What do tobacco farmers prefer in Northwestern Uganda. Makerere University Research Journal (MURJ), 1, 171-177. 